\title{
Extensive Green Roof Species Evaluations Using Digital Image Analysis
}

\author{
Jennifer M. Bousselot ${ }^{1}$, James E. Klett, and Ronda D. Koski \\ Colorado State University, Department of Horticulture and Landscape \\ Architecture, 1173 Campus Delivery, Fort Collins, CO 80523
}

Additional index words. converted two-dimensional (C2D), digital image analysis (DIA), Antennaria parvifolia, Bouteloua gracilis, Delosperma cooperi, Eriogonum umbellatum aureum 'Psdowns', Opuntia fragilis, Sedum lanceolatum

\begin{abstract}
This research examined plant area covered (plant cover) for six plant species on an existing modular extensive green roof in a semiarid climate. Species evaluated were Antennaria parvifolia Nutt., Bouteloua gracilis (Kunth) Lag., Delosperma cooperi (Hook. f.) L. Bol., Eriogonum umbellatum Torr. aureum 'Psdowns', Opuntia fragilis Nutt., and Sedum lanceolatum Torr. Many methods for measuring plant cover are subjective and based on semiquantitative measurements. This study compared digital image analysis data (DIA) with manually collected converted two-dimensional data (C2D) for plants grown on an extensive green roof. For each plant in the study, digital images and manual two-dimensional measurements were taken on four dates (at 6-week intervals) in 2008 and on four dates (at 6-week intervals) in 2009. Additionally, comparisons between DIA data and final biomass, and C2D and final biomass, were performed. Plant cover increased for all six species during the 2008 growing season. However, E. umbellatum aureum 'Psdowns' had a low overwintering rate (12.5\%) and was removed from analysis in 2009. In the spring of 2009, four of the five remaining species exhibited decreased plant cover as a result of winter dieback; the one exception was $O$. fragilis. In terms of plant cover, both quantification methods (C2D and DIA) revealed that B. gracilis and $D$. cooperi had more plant cover than $A$. parvifolia, $O$. fragilis, and $S$. lanceolatum by the end of the study. Thus, five of the six species evaluated in this study are appropriate for use in extensive green roof applications in semiarid regions. High levels of correlation were found between the DIA and C2D data sets $(r=0.77)$ averaged over the five species on all eight data collection dates. The groundcover species $(A$. parvifolia, $D$. cooperi, and $S$. lanceolatum $)$ had a higher correlation on average $(r=0.83)$ than the upright $(B$. gracilis, $r=0.70)$ and decumbent $(O$. fragilis, $r=0.65)$ species. Additionally, DIA and final biomass correlations showed parallel trends with groundcovers averaging $r=0.83$, upright $r=$ 0.64 , and decumbent $r=0.41$. Therefore, using DIA to evaluate plant cover and biomass accumulation is especially appropriate for groundcover species.
\end{abstract}

Green roofs are used to mitigate the environmental effects of urbanization worldwide (Getter and Rowe, 2006; Oberndorfer et al., 2007; Vidmar et al., 2007). There are several types of green roof systems; extensive green roofs are characterized by shallow-depth growing media, generally less than $15 \mathrm{~cm}$ deep (Getter and Rowe, 2006).

Received for publication 24 Mar. 2010. Accepted for publication 2 June 2010.

Funding and support for this study was provided by the Environmental Protection Agency through a Cooperative Agreement (83350101-0); this paper was not subject to the Agency review process.

Weston Solutions, Inc. donated the GreenGrid ${ }^{\circledR}$ modules and growing media used in this study.

Mention of a trademark, proprietary product, or vendor does not constitute a guarantee or warranty of the product by Colorado State University and does not imply its approval to the exclusion of other products or vendors that also may be suitable.

This paper is a portion of a Ph.D. dissertation submitted by Jennifer M. Bousselot.

${ }^{1}$ To whom reprint requests should be addressed; e-mailjmbouss@iastate.edu.
Extensive green roofs have not been scientifically evaluated in the high-elevation, semiarid climate of Colorado. Elsewhere in North America, research on species that can survive and thrive on extensive green roofs has revealed that succulents, predominantly Sedum taxa, outperform most non-succulents (Durhman et al., 2007; Getter and Rowe, 2009; Getter et al., 2009; Monterusso et al., 2005; Rowe et al., 2006). However, the nonsucculents tested were typically native to areas with high annual precipitation and relatively deep soil profiles. Plants native to the Rocky Mountain region, especially those that inhabit areas with shallow, rocky, welldrained soils, may be more suited for use in extensive green roof systems (Getter and Rowe, 2006).

Many plant-related studies require quantification of plant area covered or, more specifically, rate of change in plant cover over time. Quantification of plant cover is valuable for green roof studies because plant species that can cover an area quickly are preferred for green roof applications for both aesthetics and performance (White and Snodgrass, 2003).
The use of such species can reduce the cost associated with denser plantings of species that grow slower and cover less area. There are several methods for quantifying plant cover and rate of change in plant cover. However, most reported methods are subjective and not based on quantitative measurements. Typically, visual assessment or visual ratings are used to evaluate plant cover (see Olmstead et al., 2004; Richardson et al., 2001). Visual estimation of plant cover has previously been used in green roof research (Moran et al., 2004).

Manually measured plant growth indices frequently are used as a measure of plant performance. Typically, two plant diameters and plant height are used to estimate plant cover. For example, in the context of green roof research, an average of the three measurements has been used to yield a plant growth index for comparisons between plant species (Gibbs et al., 2006; Monterusso et al., 2005). Manual measurements have previously been used to predict biomass accumulation as illustrated by Spencer et al. (2006), which used shoot height in assessing growth in Arundo donax L. In the current study, a converted two-dimensional data (C2D) method was used that converts two plant diameters into the area of a circle to estimate plant cover.

Digital image analysis (DIA) is another method used to quantify plant area. The process of DIA requires periodic photographing of plants and then digital analysis of the images to quantify plant cover. Additionally, DIA has been used to quantify plant cover in several plant science disciplines, including turf sciences (Karcher and Richardson, 2003; Richardson et al., 2001), soil erosion prevention (Olmstead et al., 2004), range management (Bennett et al., 2000), and green roofs (Durhman et al., 2007).

Also, DIA can be used to estimate or validate biomass accumulation in plants. Previously, DIA of vertical silhouettes of grass plants has been used to predict biomass accumulation (Tackenberg, 2007). It has also been used to estimate aboveground legume contribution in grasslands and was later validated by biomass data (Himstedt et al., 2009).

During 2008-2009, two methods of quantifying plant cover were used to evaluate the performance of six species on an extensive green roof located in a semiarid, high-elevation region. For each of the six species in the study, approximate plant cover was obtained by manually measuring diameters of each plant and then converting those diameters (C2D) into approximate plant cover. In addition, digital images of these same plants were taken at the same intervals throughout the growing season; these images then were analyzed digitally (DIA) to quantify plant cover. The DIA data were compared with the C2D data. The specific objectives of this research were to evaluate species performance in a semiarid climate by using DIA and C2D analyses methods and comparing these two methods to plant biomass accumulation. 


\section{Materials and Methods}

Plant material. The species used in this study were selected based on the following criteria: ability to grow in semiarid, highelevation conditions (high light intensity, low relative humidity, limited soil moisture, and extreme temperature fluctuations), relatively low-growing growth habit, aesthetics, and shallow or fibrous root systems (Getter and Rowe, 2006; White and Snodgrass, 2003) (Table 1). In a study conducted on a nonirrigated extensive green roof in Michigan, Opuntia humifosa Raf., a relative of $O$. fragilis, was shown to survive the conditions characteristic of extensive green roofs (Monterusso et al., 2005). The species selected for this study, with the exception of D. cooperi, currently are not widely used in green roof applications (Bousselot et al., 2009).

The six plant species (Table 1) were planted in a Colorado State University greenhouse as monocultures in $0.61 \mathrm{~m} \times 1.22 \mathrm{~m} \times$ 10 -cm black plastic modules (GreenGrid $\AA$; Weston Solutions Inc., Vernon Hills, IL) filled with a proprietary blend of green roofgrowing media. The growing media used is well drained and designed for use in this modular green roof system. The growing media contained various percentages of heatexpanded clay, peat, perlite, and vermiculite. The growing media had $66.3 \%$ total porosity with $48.6 \%$ water content at maximum waterholding capacity, $\mathrm{pH}$ of $7.0,4.9 \%$ organic matter content, and nitrogen-phosphoruspotassium values of 105,19 , and $251 \mathrm{ppm}$, respectively.

Five of the six species were produced in 128-cell plug trays; the remaining species (O. fragilis) was produced in a 72-cell plug tray because the cactus pads were too large to be propagated in the smaller cells of the 128-cell trays. For each plant species, each of five modules was filled with growing media and planted with eight propagules on $6 \mathrm{Feb}$. 2008 in a greenhouse. Individual propagules were placed at $30-\mathrm{cm}$ centers so growth could be measured without competition from nearby plants; planting densities on green roof applications are traditionally denser. Planted modules were hand-watered every $48 \mathrm{~h}$ and maintained at $23.9^{\circ} \mathrm{C}$ day and $18.3{ }^{\circ} \mathrm{C}$ night temperatures until 20 Mar. 2008, when they were moved outdoors for hardening off. Fertilizer (Osmocote ${ }^{\circledR}$ Pro 19-5-8; Scotts, Marysville, $\mathrm{OH}$ ) was applied at $83 \mathrm{~g}$ /module on 21 Mar.

On 26 Mar. 2008, the modules were transported to and installed on the green roof above the eighth floor of the building that houses the Environmental Protection Agency (EPA) Region 8 headquarters. The research modules were placed among existing mod- ules on the green roof in a randomized complete block design. The climate conditions on the EPA Region 8 green roof during the 2008 2009 growing seasons are reported in Table 2.

During the 2008 growing season, irrigation was supplied by $3.5 \mathrm{~L} \cdot \mathrm{h}^{-1}$ drip emitters. At initiation of the study, irrigation was provided at $18.7 \mathrm{~mm} /$ week and then reduced to $8.0 \mathrm{~mm} /$ week on 15 Aug. 2008 . To provide more uniform coverage of water, the irrigation system was changed to an overhead rotator system during the 2009 growing season. Irrigation was provided at $6.4 \mathrm{~mm} /$ week starting 9 July 2009. Irrigation initiation in 2009 was delayed as a result of an unusually moist spring with precipitation $81.3 \%, 14.2 \%$, and $64.4 \%$ above normal for April, May, and June, respectively.

Data collection. Two methods of quantifying plant cover were used for this study on each individual plant: 1) C2D; and 2) DIA. C2D data were derived from manual measurements (using a ruler) of plant width and length. Based on the assumptions that the plants were roughly circular and symmetrical, plant width (w) and length $(\ell)$ were converted to plant area (A) by the equation for the area of a circle:

$$
\mathrm{A}=\pi \mathrm{r}^{2} \text { where } \mathrm{r}=(\mathrm{w}+\ell) \div 4
$$

The process of DIA required taking digital images and then determining plant cover using image analysis software. Images were taken using a FujiFilm FinePix S3000 (6x optical zoom 3.2-megapixel lens; FujiFilm Corporation, Tokyo, Japan) camera that was mounted on a Bogen Manfrotto 190xprob tripod (Ramsey, NJ) with an extendable horizontal arm. A handheld bubble level that rested on the back of the camera was used to maintain a constant camera angle relative to the plants. A portable wire frame with an attached ruler was placed on the planter tray and was included in every photograph.

Two digital images were taken for each module with four plants per image. Images were captured between 1230 and $1600 \mathrm{HR}$ to minimize the influence of the angle of the sun. Images were downloaded from the camera as $1536 \times 2048$. Photographs were then saved in 24-bitmap format to ensure ease of use in the DIA program. Some colors of the growing media were found to be similar to some of the colors of the plant foliage; thus, the growing media was removed from each image before DIA using the free-form select tool in Microsoft ${ }^{\circledR}$ Paint (Microsoft Corporation, Redmond, WA). Visual determination between growing media and plants was clear despite some overlap in color.

The DIA was performed on adjusted images using SigmaScan Pro 5.0 (Systat
Software Inc., San Jose, CA) image analysis software to yield plant cover. Each image was two-point calibrated in SigmaScan using the ruler present in the image. This calibration quantifies the area per pixel so results can be analyzed in common area units (i.e., $\mathrm{cm}^{2}$ ). Each plant (four per image) was individually evaluated after cropping to remove all additional growing media in the image.

The color spectrum in SigmaScan had a hue range of 0 to 255 and a saturation range of 0 to 100 . The plants in this study were variable in color but generally were green and had hue values within the range of 30 to 120 and saturation values within the range of 10 to 100 . Similar to the methods used by Purcell (2000), occasionally these values had to be adjusted slightly ( $\pm 5 \%$ ) to correct for seasonal foliage color change. Once the range of colors was determined, an overlay was applied to indicate the green pixels to be counted for plant cover. Then, the measurement objects function, which quantifies area under the overlay, was selected and the output displayed in a worksheet. The output, based on the calibration, was given in square centimeters.

One of the five species, D. cooperi, had inflorescences that were outside the 30 to 120 hue and 10 to 100 saturation ranges. The remaining species either had inflorescences within that range or did not bloom during the trial period. To account for the red D. cooperi inflorescence as a contribution to DIA plant cover, an additional red pixel range of hue 200 to 255 and saturation 10 to 100 was included during seasonal bloom of each year (Fig. 1).

The C2D and DIA data were collected on eight dates over 2 years and were analyzed to determine plant cover. Four dates in 2008 at 6-week intervals (14 May, 25 June, 6 Aug., and 16 Sept.) and four dates at 6-week intervals in 2009 (13 May, 24 June, 5 Aug., and 15 Sept.) were evaluated. Additionally, all aboveground plant biomass was harvested on 15 Oct. or 22 Oct. 2009. Dry biomass was determined after drying at $70{ }^{\circ} \mathrm{C}$ for at least $72 \mathrm{~h}$.

Statistical analysis. A repeated-measures analysis of variance STAT/GLIMMIX (general linear model for mixture distributions) procedure in SAS ${ }^{\circledR}$ Version 9.02 (SAS Institute Inc., Cary, NC) was performed using $t$ tests $(\alpha=0.05)$ for multiple comparisons of means to show differences in plant cover between species for both the DIA and C2D data sets. Data for analysis were transformed to the square root scale to equalize and normalize the residuals. Results have GLIMMIX significant differences $(P \leq 0.05)$ unless otherwise noted.

Table 1. Plant species evaluated in the study.

\begin{tabular}{|c|c|c|c|c|c|c|}
\hline Species & $\begin{array}{l}\text { Antennaria } \\
\text { parvifolia }\end{array}$ & $\begin{array}{l}\text { Bouteloua } \\
\text { gracilis }\end{array}$ & $\begin{array}{l}\text { Delosperma } \\
\text { cooperi }\end{array}$ & $\begin{array}{l}\text { Eriogonum umbellatum } \\
\text { aureum 'Psdowns' }\end{array}$ & Opuntia fragilis & Sedum lanceolatum \\
\hline Common name & Small-leaf pussytoes & Blue grama & Hardy ice plant & $\begin{array}{c}\text { Kannah Creek }{ }^{\circledR} \\
\text { buckwheat }\end{array}$ & Brittle pricklypear & Spearleaf stonecrop \\
\hline Growth habit & Groundcover & Upright (grass) & Groundcover & Groundcover & Decumbent (cactus) & Groundcover \\
\hline
\end{tabular}


Correlation coefficients $(r)$ were used to evaluate the relationship between the two observed data sets. Regression $\left(r^{2}\right)$ was not used because most often it evaluates the fit between observed versus predicted values instead of evaluating the relationship between two observed data sets such as with correlation. Correlations between C2D and DIA data sets as well as between DIA and biomass and $\mathrm{C} 2 \mathrm{D}$ and biomass data sets were determined in SAS using PROC COR.

\section{Results and Discussion}

Every individual plant of each of the six species survived the 2008 growing season. Overwintering during the 2008-2009 season was $100 \%$ successful for four of the six species. Antennaria parvifolia, which had a $65 \%$ overwintering survival rate, was included in the data analysis. However, E. umbellatum aureum 'Psdowns', which had a $12.5 \%$ overwintering rate, was not included in the data analysis. Plant cover is reported in terms of days from trial initiation with $1 \mathrm{~d}$ after install being the day after the modules were placed on the green roof (27 Mar. 2008) and $49 \mathrm{~d}$ after install being the first date of comparison (14 May 2008).

Species evaluations. Plant cover by DIA over the eight consecutive evaluation dates is shown in Figure 2. Plant cover was significantly different on each date for most species comparisons. On the first date of comparison, $49 \mathrm{~d}$ after install, all species were significantly different from each other $(P \leq 0.05)$ except $B$. gracilis and $O$. fragilis (these two species had the least cover on this day). On 91 d after install, all species were significantly different from each other except $B$. gracilis and $S$. lanceolatum. On the final two dates of the first year, $133 \mathrm{~d}$ and $174 \mathrm{~d}$ after install, all species were significantly different from each other in plant cover.

Similar to what was observed during 2008, most interspecies plant cover comparisons on each date in 2009 were significant. However, on $413 \mathrm{~d}$ after install, the comparison between $A$. parvifolia and B. gracilis was not significant. By $455 \mathrm{~d}$ after install, plant cover for many of the species yielded similar values (Fig. 2) resulting in two sets of comparisons that were not significant: between $B$. gracilis and $D$. cooperi and between D. cooperi and S. lanceolatum. As the species recovered in plant cover from overwintering stress, all comparisons were significant again except for between $O$. fragilis and $S$. lanceolatum on $497 \mathrm{~d}$ after install and between $B$. gracilis and D. cooperi on $538 \mathrm{~d}$ after install.

The C2D data for plant cover are represented in Figure 3. Nearly every species comparison on each date yielded significant differences in plant cover. During 2008, the comparisons between A. parvifolia and $S$. lanceolatum on $49 \mathrm{~d}$ after install and on 174 $\mathrm{d}$ after install were not significantly different; all remaining species comparisons were significantly different that year. During 2009, all comparisons were significant except for the comparisons between $A$. parvifolia and
Table 2. Mean monthly weather data for the 2008-2009 growing seasons.

\begin{tabular}{|c|c|c|c|c|c|c|c|c|c|c|}
\hline \multirow[b]{2}{*}{ Weather } & \multicolumn{2}{|c|}{ May } & \multicolumn{2}{|c|}{ June } & \multicolumn{2}{|c|}{ July } & \multicolumn{2}{|c|}{ August } & \multicolumn{2}{|c|}{ September } \\
\hline & $2008^{z}$ & $2009^{y}$ & $2008^{z}$ & $2009^{y}$ & $2008^{z}$ & $2009^{y}$ & $2008^{y}$ & $2009^{y}$ & $2008^{y}$ & $2009^{y}$ \\
\hline $\begin{array}{l}\text { Minimum daily } \\
\text { temperature }\left({ }^{\circ} \mathrm{C}\right)\end{array}$ & 6.7 & 10.7 & 11.9 & 13.5 & 16.8 & 16.3 & 16.7 & 15.9 & 11.3 & 11.8 \\
\hline $\begin{array}{l}\text { Maximum daily } \\
\text { temperature }\left({ }^{\circ} \mathrm{C}\right)\end{array}$ & 22.6 & 24.7 & 29.4 & 28.3 & 34.4 & 31.8 & 31.7 & 32.0 & 26.5 & 27.6 \\
\hline $\begin{array}{l}\text { Precipitation total } \\
(\mathrm{mm})\end{array}$ & 64.3 & 56.4 & 16.8 & 41.3 & 3.8 & 63.5 & 8.4 & 21.8 & 16.0 & 17.5 \\
\hline
\end{tabular}

${ }^{\mathrm{z}}$ National Weather Service station (ID: 052223) at Denver Water (1600 W. 12th Avenue, Denver, CO) collected $2.6 \mathrm{~km}$ away from green roof.

${ }^{\mathrm{y}}$ Campbell Scientific (Logan, UT) weather station located on the EPA Region 8 green roof (1595 Wynkoop Street, Denver, CO).
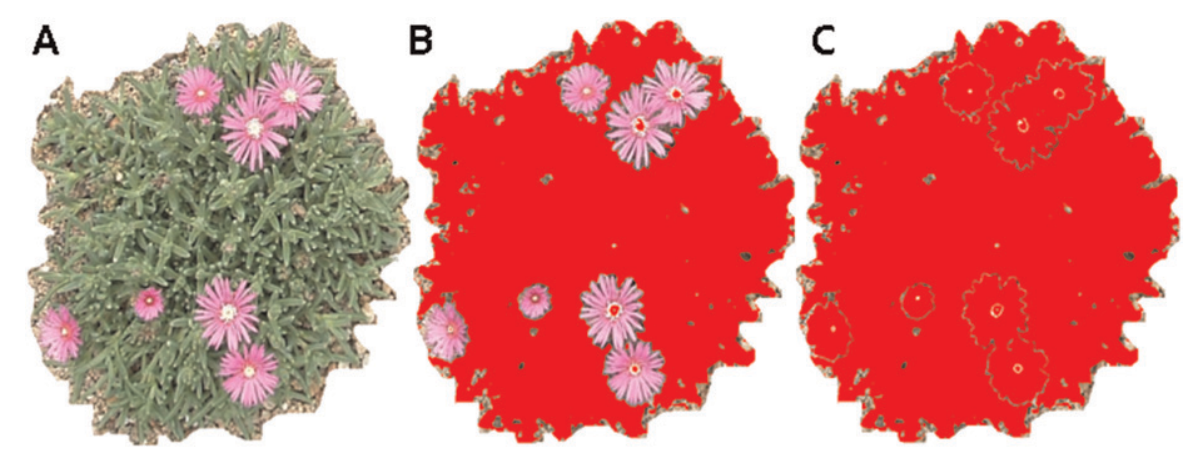

Fig. 1. Example of a Delosperma cooperi plant during digital image analysis (DIA) in SigmaScan Pro 5.0 image analysis program: (A) digital image before analysis, (B) with overlay for green pixel range, and (C) with overlay of green and red pixel range to include inflorescence.

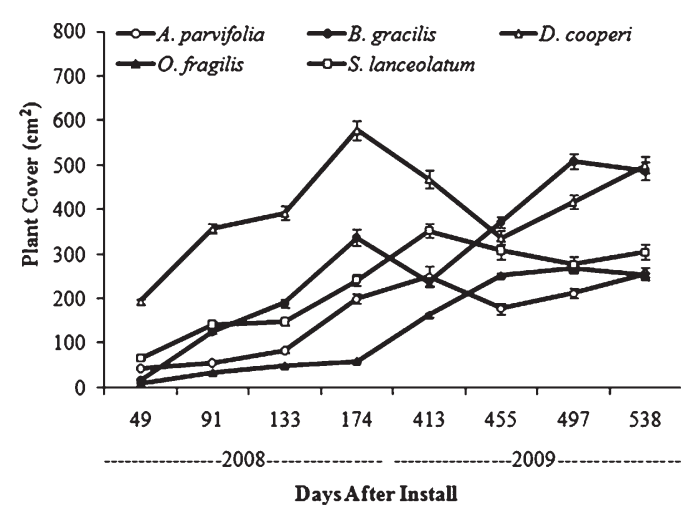

Fig. 2. Plant cover on eight consecutive evaluation dates over two growing seasons (2008-2009) as determined by digital image analysis (DIA) for the five experimental plant species. Error bars represent SE of the mean.

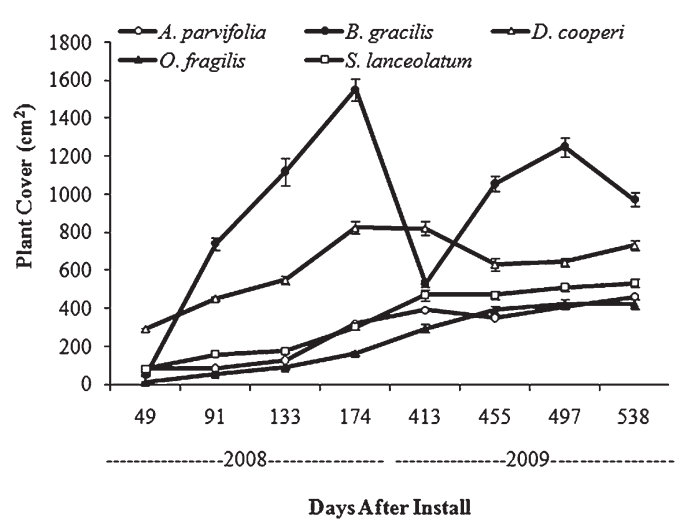

Fig. 3. Plant cover on eight consecutive evaluation dates over two growing seasons (2008-2009) as determined by converted two-dimensional (C2D) analysis for the five plant species. Error bars represent SE of the mean. 
O. fragilis on $413 \mathrm{~d}$ after install and again on $538 \mathrm{~d}$ after install.

In general, all species increased in plant cover during 2008 for both DIA and C2D data sets (Figs. 2 and 3). However, during 2009 , four of the five species showed temporary declines in plant cover, the exception being $O$. fragilis. This reduction in plant cover is likely a result of overwintering stress. A similar phenomenon can be observed in the growth index graphs for species evaluated in a Michigan study, specifically, Agastache foeniculum, Aster laevis, Coreopsis lanceolata, and several other species (Monterusso et al., 2005).

On $538 \mathrm{~d}$ after install, the final date of plant cover comparisons, the two species with the highest plant cover were $B$. gracilis and $D$. cooperi with the remaining three species closely grouped in plant cover: $A$. parvifolia, $O$. fragilis, and $S$. lanceolatum. Therefore, based on evaluations over two consecutive growing seasons on an extensive green roof, $B$. gracilis and $D$. cooperi were more successful than $A$. parvifolia, $O$. fragilis, and $S$. lanceolatum. However, $A$. parvifolia, $O$. fragilis, and $S$. lanceolatum survived and resulted in a net increase in plant cover so these species should still be considered for use on extensive green roofs.

The intent for the selection of the species evaluated in this study was to add diversity to the list of species suitable for extensive green roof cultivation in a semiarid climate. These species should survive the low moisture conditions of non-irrigated roofs in areas with higher annual precipitation than the semiarid region in which this study was situated. With the exception of E. umbellatum aureum 'Psdowns', the species evaluated in this study can be recommended for use on extensive green roofs.

Correlation coefficient analysis. High levels of correlation were found between the DIA and C2D data sets averaged over the five species and overall eight data collection dates (mean $r=0.77$ ). Over all correlations between the $\mathrm{C} 2 \mathrm{D}$ and DIA data sets were higher for the three groundcover species: A. parvifolia, D. copperi, and S. lanceolatum (mean $r=0.83$ ) (Table 3). The remaining two species had lower but still good correlations between the two data sets: $B$. gracilis with an upright growth habit and $O$. fragilis with a decumbent growth habit.

Of the species evaluated in this study, the groundcover $A$. parvifolia had the highest mean correlation coefficient between the two data sets. The lowest correlation occurred on $455 \mathrm{~d}$ after install, after the plants had come out of winter dormancy with irregular regrowth patterns (Fig. 4A). Because C2D data measure plant diameters at the widest points of the plant axes, areas of dieback within those diameters are included in the analysis, giving an overestimation of actual plant cover. Delosperma cooperi, with a similar growth habit to A. parvifolia, resulted in a similar pattern in correlation coefficients.

The lower correlation value between the two data sets for $B$. gracilis can be explained

Table 3. Correlation coefficients $(r)$ between converted two-dimensional (C2D) and digital image analysis (DIA) data sets for eight dates and overall mean for the five species ( $\mathrm{n}=40$, except $A$. parvifolia where $\mathrm{n}=26$ in 2009 only).

\begin{tabular}{|c|c|c|c|c|c|c|c|c|c|}
\hline \multirow{2}{*}{$\begin{array}{l}\text { Correlations }(r) \\
\text { Species }\end{array}$} & \multicolumn{4}{|c|}{2008 Growing season } & \multicolumn{4}{|c|}{2009 Growing season } & \multirow[b]{2}{*}{ Mean } \\
\hline & $\overline{49 \mathrm{~d}}$ & $91 \mathrm{~d}$ & $133 \mathrm{~d}$ & $174 \mathrm{~d}$ & $413 \mathrm{~d}$ & $455 \mathrm{~d}$ & $497 \mathrm{~d}$ & $538 \mathrm{~d}$ & \\
\hline A. parvifolia & 0.84 & 0.91 & 0.92 & 0.95 & 0.97 & 0.78 & 0.88 & 0.84 & 0.89 \\
\hline B. gracilis & 0.84 & 0.78 & 0.59 & 0.63 & 0.76 & 0.64 & 0.70 & 0.65 & 0.70 \\
\hline D. cooperi & 0.84 & 0.86 & 0.96 & 0.90 & 0.83 & 0.78 & 0.70 & 0.86 & 0.84 \\
\hline O. fragilis & 0.71 & 0.42 & 0.70 & 0.71 & 0.61 & 0.58 & 0.70 & 0.76 & 0.65 \\
\hline S. lanceolatum & 0.92 & 0.95 & 0.95 & 0.97 & 0.89 & 0.49 & 0.36 & 0.47 & 0.75 \\
\hline
\end{tabular}

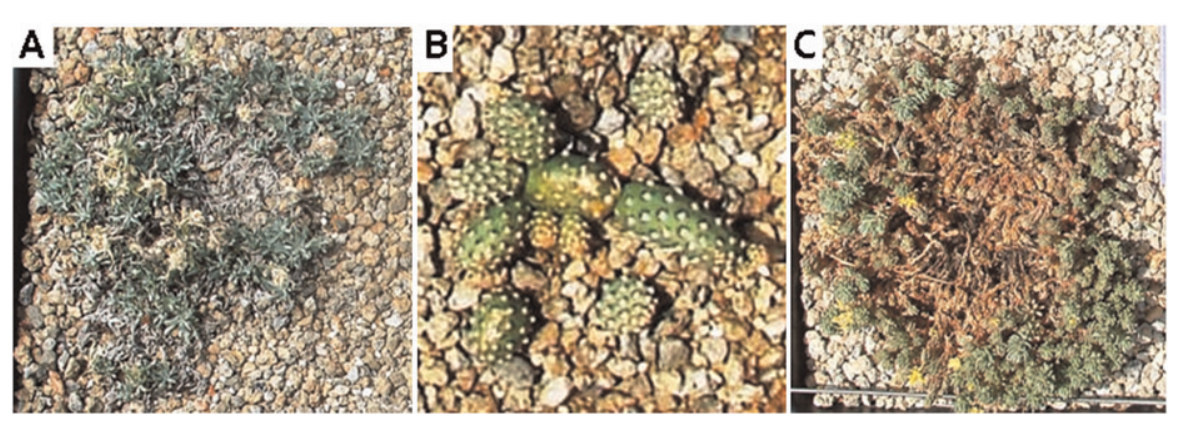

Fig. 4. Examples of plant images used in digital image analysis (DIA) for (A) Antennaria parvifolia (on $455 \mathrm{~d}$ after install) with an irregular growth habit after overwintering, (B) Opuntia fragilis (on 91 $\mathrm{d}$ after install) replanted after physical damage, and (C) Sedum lanceolatum (on $455 \mathrm{~d}$ after install) with post-inflorescence center dieback. Images are for illustration purposes and are not equal in scale.

by a much more upright, open, and sparse growth habit compared with the groundcover species. Therefore, measurements of plant size by hand (C2D) will show larger cover relative to the DIA results, which quantify only the amount of green plant tissue in a given area. The DIA data quantify only plant cover visible from above, whereas $\mathrm{C} 2 \mathrm{D}$ data assume that all of the area within the measured diameters is plant cover. This phenomenon is evident by a visual comparison of the discrepancy between the scale of plant cover curves in Figures 2 and 3 for this species. The correlation coefficient was the highest for $B$. gracilis on $49 \mathrm{~d}$ after install when it had the shortest, densest growth habit.

The highest correlations for $O$. fragilis occurred in September of each year when the pads of the cacti were filled out. This agrees with results from a green roof study in Michigan in which $O$. humifosa, a native cactus, attained the largest size in September (Monterusso et al., 2005).

On $91 \mathrm{~d}$ after install, $O$. fragilis had a low correlation because in two of the five blocks, the entire module of eight individual cacti had recently been physically damaged (pads removed) by extension cords that were dragged over the plants. All of the pads that were removed from the parent cactus had to be "replanted" near the parent plant. Rooting and regrowth occurred rapidly, but the manual measurements of those plants on $91 \mathrm{~d}$ after install yielded superficially larger results than they would have if the entire plant were intact (Fig. 4B). This is because the individual cactus pads could not be placed as closely to the parent plant at replanting as they were while on the plant. Therefore, a wider set of diameters was recorded after replanting. If the two damaged blocks are removed from the correlation analysis on that date, the value improves for the remaining three blocks ( $r=$ $0.67)$.

Correlations in 2008 were strong for $S$. lanceolatum (mean $r=0.95$ ). However, the 2-year mean correlation coefficient was affected by the lower correlation values during 2009. In 2009, bloom occurred early in the season in three of the five blocks and after the inflorescence senesced (before $455 \mathrm{~d}$ after install), the center of each plant died out leaving an irregular circular area of green around the perimeter of the plant (Fig. 4C). Therefore, the C2D measurements showed the plant to be much larger than what the DIA quantified; hence, the reduced correlation values for 2009 .

Time invested for each method of quantifying plant cover was $\approx 1$ min per plant per measurement date for the C2D method and $\approx 2$ min per plant per date for the DIA method, which is similar to Richardson et al. (2001). Although the DIA method took longer than the C2D method in this study, several factors could be altered in future studies to reduce the time required for DIA. For example, if the color contrast between the growing media and the foliage were greater, the step in Microsoft $\AA$ Paint could be avoided, which was $\approx 20$ s per plant per date. Additionally, if the camera tripod was located in a fixed location and the modules were the mobile portion, images would not have to be calibrated individually but instead could be batch calibrated, as described in Karcher and Richardson (2005).

Although the time commitment may have been higher using DIA in this study, correlations indicate that accuracy was improved. In four of the five species discussed (the exception being $D$. cooperi), date or growth period discrepancies between the DIA and C2D data sets could be attributed to overestimation of plant cover by the C2D measurements. This 
Table 4. Correlations between digital image analysis (DIA) and biomass, and converted two-dimensional (C2D) and biomass, on final date of DIA and C2D data collection (538 $\mathrm{d}$ after install) for the five species $(\mathrm{n}=40$, except $A$. parvifolia where $\mathrm{n}=26$ ).

\begin{tabular}{lcc}
\hline Species & $\begin{array}{c}\text { DIA } \\
\text { correlations }(r)\end{array}$ & $\begin{array}{c}\text { C2D } \\
\text { correlations }(r)\end{array}$ \\
\hline A. parvifolia & 0.79 & 0.54 \\
B. gracilis & 0.64 & 0.19 \\
D. cooperi & 0.87 & 0.79 \\
O. fragilis & 0.41 & 0.18 \\
S. lanceolatum & 0.84 & 0.40 \\
\hline
\end{tabular}

is further supported by the difference in plant cover values between Figures 2 and 3, especially for $B$. gracilis, which shows plant cover at a much higher value for C2D (Fig. 3) than DIA (Fig. 2). The difference is an overestimation of plant cover for the C2D method, as discussed previously.

Biomass from harvested plants was correlated with the last date of DIA and C2D to evaluate how well plant cover measurements corresponded with individual plant biomass accumulation (Table 4). In general, correlations between the last date of DIA and biomass data were high (mean $r=0.83$ ) for the three groundcover plants: A. parvifolia, D. cooperi, and S. lanceolatum. Bouteloua gracilis with a more upright growth habit had a lower correlation likely because images taken from directly above would not account for biomass as if taken from the vertical like in Tackenberg (2007). Correlations for $O$. fragilis were the lowest among the species in this study. This low correlation was attributed to the decumbent growth habit of this species, specifically how the pads were aligned both vertically and horizontally. Thus, similar to B. gracilis, vertical biomass was not accounted for when an image was taken from directly above the plant (Fig. 4B).

Although plant diameters, not height, were used in the current study, biomass was only highly correlated to C2D for one of the five species, D. cooperi; the remaining four species had low correlation values. It appears the low correlations of those species are parallel to the low correlations between DIA and $\mathrm{C} 2 \mathrm{D}$; the $\mathrm{C} 2 \mathrm{D}$ data did not account for the irregular growth patterns, whereas DIA did take those growth patterns into account.

\section{Conclusion}

All six species increased in plant cover during the first growing season, but the trend did not continue for the second growing season. Survival over the winter season was successful for five of the six species; $E$. umbellatum aureum 'Psdowns' experienced low winter survival and was removed from the study in 2009. In 2009, there was a temporary reduction in plant cover as a result of overwintering stress for four of the five remaining species, the exception being $O$. fragilis.

At the end of the study, B. gracilis and $D$. cooperi had outperformed $A$. parvifolia, $O$. fragilis, and $S$. lanceolatum, indicating that $B$. gracilis and D. cooperi are more suitable for green roof culture in semiarid regions. However, because all five of these species survived over the 2 years of this study, all five species should be considered for use on extensive green roofs.

Owing to the high correlation coefficient values between DIA and C2D for the groundcover species (A. parvifolia, D. cooperi, and $S$. lanceolatum), these two methods are useful for quantifying plant cover. The DIA analysis appears to be a reliable substitution for the less accurate C2D method. Additionally, DIA can be used to estimate biomass accumulation, specifically for groundcover species. However, C2D data did not correlate well with biomass data in this study.

\section{Literature Cited}

Bennett, L.T., T.S. Judd, and M.A. Adams. 2000 Close-range vertical photography for measuring cover changes in perennial grasslands. J. Range Manage. 53:634-641.

Bousselot, J.M., J.E. Klett, and R.D. Koski. 2009. High elevation semi-arid taxa: Evaluations on an extensive green roof. Proc. of 7th North Amer. Green Roof Conf.: Greening rooftops for sustainable communities, Atlanta, GA, 3-5 June 2009. The Cardinal Group, Toronto, Canada.

Durhman, A.K., D.B. Rowe, and C.L. Rugh. 2007. Effect of substrate depth on initial growth, coverage, and survival of 25 succulent green roof plant taxa. HortScience 42:588-595.

Getter, K.L. and D.B. Rowe. 2006. The role of extensive green roofs in sustainable development. HortScience 41:1276-1285.

Getter, K.L. and D.B. Rowe. 2009. Substrate depth influences Sedum plant community on a green roof. HortScience 44:401-407.

Getter, K.L., D.B. Rowe, and B.M. Cregg. 2009. Solar radiation intensity influences extensie green roof plant communities. Urban For. Urban Green. 8:269-281.

Gibbs, J., K. Luckett, V. Jost, S. Morgan, T. Yan, and W. Retzlaff. 2006. Evaluating performance of a green roof system with different growing mediums, Sedum species and fertilizer treatments. Proc. of Midwest Regional Green Roof Symp., Edwardsville, IL, 30 June 2006.

Himstedt, M., T. Fricke, and M. Wachendorf. 2009. Determining the contribution of legumes in legume-grass mixtures using digital image analysis. Crop Sci. 49:1910.

Karcher, D.E. and M.D. Richardson. 2003. Quantifying turfgrass color using digital image analysis. Crop Sci. 43:943-951.

Karcher, D.E. and M.D. Richardson. 2005. Batch analysis of digital images to evaluate turfgrass characteristics. Crop Sci. 45:1536-1539.

Monterusso, M.A., D.B. Rowe, and C.L. Rugh. 2005. Establishment and persistence of Sedum spp. and native taxa for green roof applications. HortScience 40:391-396.

Moran, A., B. Hunt, and G. Jennings. 2004. A North Carolina field study to evaluate greenroof runoff quantity, runoff quality, and plant growth, p. 446-460. Proc. of 2nd North Amer. Green Roof Conf:: Greening rooftops for sustainable communities, Portland, OR, 2-4 June 2004. The Cardinal Group, Toronto, Canada.

Oberndorfer, E., J. Lundholm, B. Bass, R.R. Coffman, H. Doshi, N. Dunnett, S. Gaffin, M. Köhler, K.K.Y. Liu, and B. Rowe. 2007. Green roofs as urban ecosystems: Ecological structures, functions, and services. Bioscience 57:823-833.

Olmstead, M.A., R. Wample, S. Greene, and J. Tarara. 2004. Nondestructive measurements of vegetative cover using digital image analysis. HortScience 39:55-59.

Purcell, L.C. 2000. Soybean canopy coverage and light interception measurements using digital imagery. Crop Sci. 40:834-837.

Richardson, M.D., D.E. Karcher, and L.C. Purcell. 2001. Quantifying turfgrass cover using digital image analysis. Crop Sci. 41:1884-1888.

Rowe, D.B., M.A. Monterusso, and C.L. Rugh. 2006. Assessment of heat-expanded slate and fertility requirements in green roof substrates. HortTechnology 16:471-477.

Spencer, D.F., P.S. Liow, W.K. Chan, G.G. Ksander, and K.D. Getsinger. 2006. Estimating Arundo donax shoot biomass. Aquat. Bot. 84: 272-276.

Tackenberg, O. 2007. A new method for nondestructive measurement of biomass, growth rates, vertical biomass distribution and dry matter content based on digital image analysis. Ann. Bot. (Lond.) 99:777-783.

Vidmar, J., K. Kelley, and R. Berghage. 2007. Background educational and promotional materials for green roofs: A series of articles to promote understanding of the benefits of using green roofs, p. 71-94. In: Berghage, R., A. Jarrett, D. Beattie, K. Kelley, S. Husain, F. Rezai, B. Long, A. Negassi, R. Cameron, and W. Hunt (eds.). Quantifying evaporation and transpirational water losses from green roofs and green roof media capacity for neutralizing acid rain. Penn. State Univ., State College, PA.

White, J.W. and E. Snodgrass. 2003. Extensive greenroof plant selection and characteristics, p. 166-176. Proc. of 1st North Amer. Green Roof Conf.: Greening Rooftops for Sustainable Communities, Chicago, IL, 29-30 May 2003. The Cardinal Group, Toronto, Canada. 